\title{
Carbon Stock Stratification of Peat Soils in South Kalimantan, Indonesia
}

\author{
SITI NURZAKIAH ${ }^{1}$, MUHAMMAD NOOR ${ }^{1}$ AND DEDI NURSYAMSI ${ }^{2}$ \\ ${ }^{1}$ Indonesian Swampland Agriculture Research Institute. Banjarbaru, South Kalimantan \\ ${ }^{2}$ Indonesian Center for Agricultural Land Resources Research and Development, Bogor
}

\begin{abstract}
Carbon stock in peat soils is very high, it is necessary to prudent in its management because peat soils is emitting greenhouse gases such as $\mathrm{CO}_{2}$ during land clearing due to oxidation of peat layer. This research was conducted to study soil carbon stock stratification in relation to soil physical and chemical properties. The carbon stock stratification was based on maturity degrees of peat. The study was conducted in Pulau Damar Village, Hulu Sungai Utara District, South Kalimantan Province on land use rubber. The location of the study area was determined by using the purposive sampling method. All data obtained were analyzed by Excel spreadsheets and drawn on a CorelDraw 12. The results showed that the amount of carbon stock was influenced by the maturity degrees of peats, peat sapric degres has higher carbon stock than of hemik and fibric with a ratio of 2.0: 1.5: 1. The relationship between soil carbon stock with soil physic (Bulk Density, BD) and chemical properties (pH, Eh, Fe, and total-N) were not significantly.
\end{abstract}

Keywords : Carbon stock, maturity degree of peat, soil physical and chemical properties.

\section{INTRODUCTION}

Peatlands has the potential to be developed as agricultural land with due regard to environmental aspects. Land use changes, including peat forest conversion will bring a change in the rate of $\mathrm{C}$ emission and sequestration. Land use change from natural forest to agricultural land generally does not occur directly. Peatland clearance which began in the 1970s carried through several stages before it becomes agricultural land. As a result of illegal logging, natural forest turns into a secondary forest or degraded forest and then into plantations. The impact due to changes in land use include the following changes in hydrological patterns, erosion and downstream sedimentation, reduction in biodiversity, decreasing capacity for carbon sequestration, and direct emissions of carbon dioxide and other greenhouse gases.

\footnotetext{
Correspondence: Siti Nurzakiah, Indonesian Swampland Agriculture Research Institute.

J1. Kebun Karet, Loktabat Utara, PO. Box 31, Banjarbaru, South Kalimantan

E-mail: zakiah_balittra@yahoo.co.id
}

The extent to which land use change affects the environmental services provided by forests depends on the nature of the forest and on the nature of the change in use (Pagiola 2000).

Peatlands have a high carbon stocks as a whole peat and plants that grow above it is the stored carbon. The total carbon stored in peatlands is estimated at 550 Giga tons (Joosten 2009). Carbon stocks in peat soil is greater than that stored in the plant biomass. The above-ground biomass (with associated debris) reached a maximum of about $150 \mathrm{C}$ $\mathrm{Mg} \mathrm{ha}^{-1}$ (Morison et al. 2010). Wardah et al. (2011) reported that above ground C-stock in the complex agroforestry (combination of different types of trees, shrubs and plant) of Lore Lindu National Park, Central Sulawesi were $98.46 \mathrm{Mg} \mathrm{ha}^{-1}$. Soil carbon stocks are correlated with the thickness of peat (Kiely et al. 2009, Morison et al. 2010, Wellock, et al. 2011) so that carbon stocks can be predicted by using peat depth. In peats dominated by fibric maturity degree with the depth of 36 $338 \mathrm{~cm}$ have carbon stocks varying from 161.8 to $1142.2 \mathrm{Mg} \mathrm{C} \mathrm{ha}^{-1}$, while the shallow peats in the area have carbon stocks of $3.45 \mathrm{Mg} \mathrm{C}$ $\mathrm{ha}^{-1} \mathrm{~cm}^{-1}$ (Nurzakiah et al. 2013). 
Peat soils in Indonesia has a variability both of thickness and maturity as well as peatforming materials of different origin and can be found at various landform. In the inland peat can be found layers which are all from peat substance or mineral substance insertions in the midst of peat substance. The presence of mineral substance in the peat will affect soil fertility due to nutrient enrichment of river sediment. This condition affects physical and chemical properties of soil such as bulk density (BD), pH, Eh, ash content, Fe and $\mathrm{N}$ content and therefore contributes to soil fertility rate. Soil fertility is one of factors that affect the amount of carbon stock in addition to thickness and maturity degree of peat. Fiber content can be used as an indicator of the maturity degree of peat. The difference in the amount of carbon stock will affect the potential carbon emissions.

Soil $\mathrm{pH}$ is a basic soil properties and influences the redox potential (Eh). Redox potential has an important role in geochemical processes. Almost all chemical reactions occur due to the transfer of electrons from the ion to another ion. Availability, concentration and mobility of elements such as Fe, $\mathrm{N}$ and $\mathrm{C}$ are determined by the redox potential (Borch et al., 2010). Soil physical properties is related with peat decomposition and compaction. Bulk density and content of organic carbon influence variation carbon stock in peatland. Hooijer et al. (2006) reported that soil carbon stock in Southeast Asia depend on the BD and the percentage of peat carbon material. This research was conducted to study soil carbon stocks stratification in relation to soil physical and chemical properties.

\section{MATERIALS AND METHODS}

\section{Study Sites}

The study was conducted by a survey method, and then purposive sampling method. The study was in Pulau Damar Village, Hulu sungai Utara District, South Kalimantan Province (coordinates of $02^{\circ} 44^{\prime} 29.4$ " $\mathrm{S}$ and $\left.115^{\circ} 37^{\prime} 39.9^{\prime \prime} \mathrm{E}\right)$ on rubber.

\section{Soil Sampling and Determination of Soil Carbon Stock}

Soil sampling was conducted on March 2012 in the nine points of observation (transect system) assuming there are variation in thickness of peat and other soil properties. Carbon stock stratification was based on maturity degree of peat. Soil sampling with a peat auger (Eijkelkamp model) was conducted until substratum. In each point observations were performed two times of soil sampling with a peat auger in the points adjacent to each other. The two points of the soil sampling with details of one points for the determination of carbon stocks and the other points for the analysis of $\mathrm{pH}, \mathrm{Eh}, \mathrm{Fe}$ and Ncontent.

Parameters to determine carbon stock was bulk density (t.m ${ }^{-3}$, gravimetric method), carbon content (wt \%, dry ashing method) and thickness of peat (observed directly in field using peat auger Eijkelkamp) (Agus, 2009). Other parameters were widely peat soils and peat maturity degrees. Soil organic matter content $(\mathrm{OM})$ was calculated based on $\%$ of the soil dry weight, namely: OM (wt $\%)=$ $(\mathrm{DW}-\mathrm{AW}) / \mathrm{DW} * 100 \%$, where AW was ash weight determined with ashing method in furnace at a temperature of $550{ }^{\circ} \mathrm{C}$ for 6 hours while DW was soil dry weight. Degrees of soil organic C (Org-C \% by weight) was calculated based on the conversion of organic matter to the constant 1.724 [Org-C: wt $\%$ ) = $\mathrm{OM} / 1.724]$ and Org-C (\% vol) was weight of carbon per unit soil volume (t.m $\left.{ }^{-3}\right)$, namely: $[$ Org-C $(\%$ vol $)=$ Org-C $(\%$ by weight $) * \mathrm{BD}-$ ash]. Carbon stocks in the soil was weight of $\mathrm{C}$ in a unit volume of soil, namely: $\mathrm{C}$-stock $=$ Org-C (\% vol $) * \mathrm{~A} * \mathrm{~L}$, where $\mathrm{L}$ was peat soil area $\left(\mathrm{m}^{2}\right)$ and a was thickness of the peat $(\mathrm{m})$.

The regression and correlation test was conducted to determine the relationship of carbon stock with soils properties (BD, $\mathrm{pH}$, $\mathrm{Eh}, \mathrm{Fe}$, and total-N). All data obtained were analyzed by Excel spreadsheets and drawn by a Corel Draw 12. 


\section{RESULTS AND DISCUSSION}

The thickness of peat at the study site ranged from $310-465 \mathrm{~cm}$ with a maturity degree of peat which dominant is fibric. At this location there are mineral substance insertions in the midst of peat substance with carbon stock in the amount of $2251.68 \pm$ 152.40 t.ha $^{-1}$ (the thickness of mineral substance is $3-24 \mathrm{~cm})$. When the inserted mineral substance was neglected, the obtained carbon stock was $2025.21 \pm 132.77$ t.ha $^{-1}$.

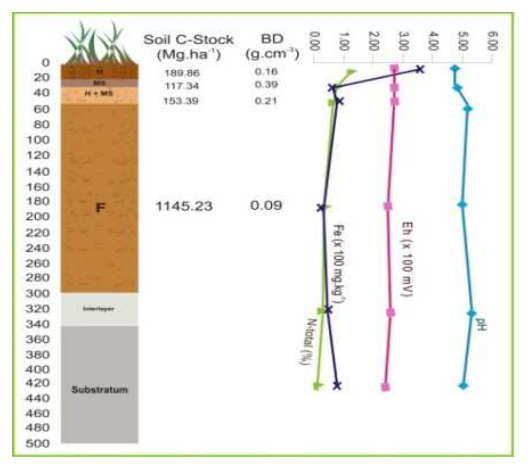

(1)

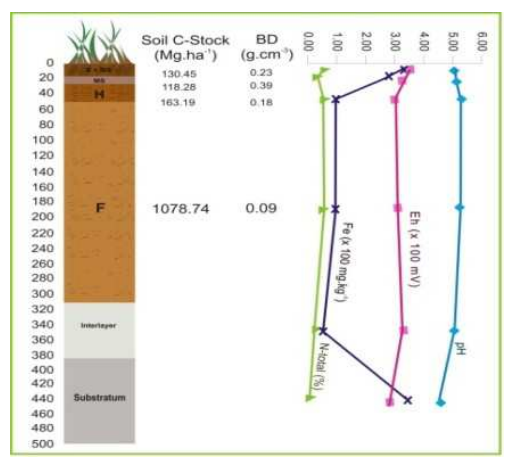

(2)

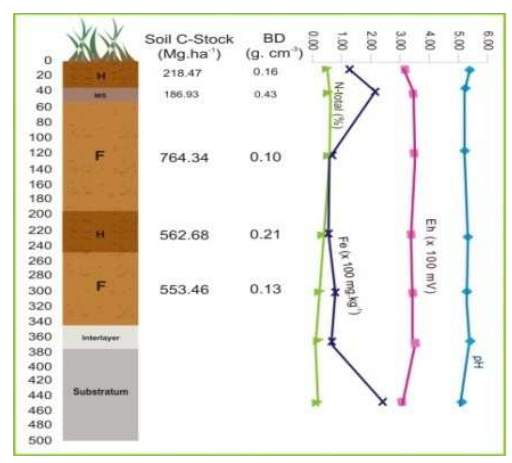

(3)

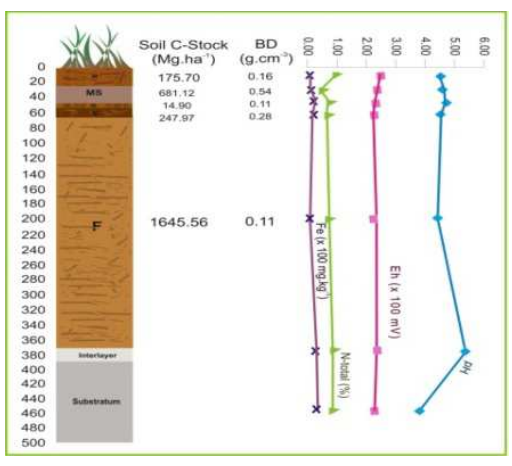

(4)

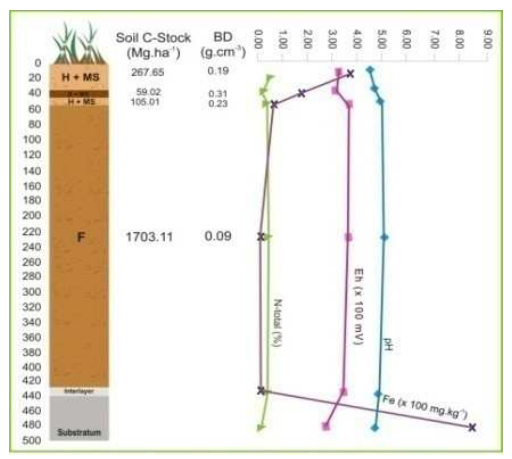

(5)

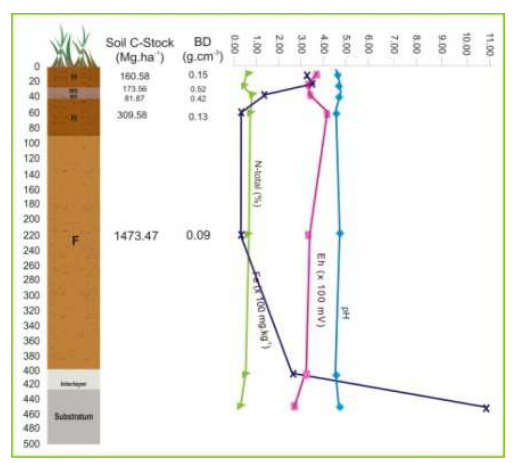

(6)

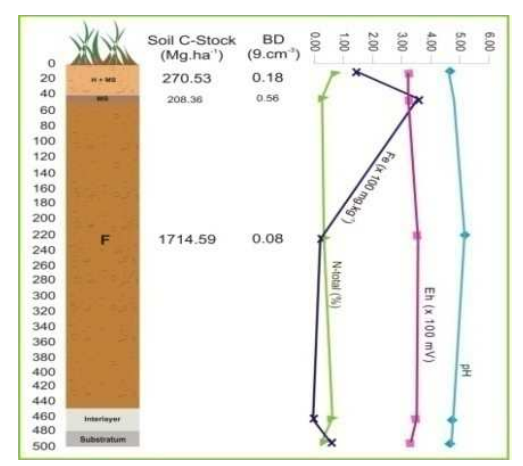

(7)

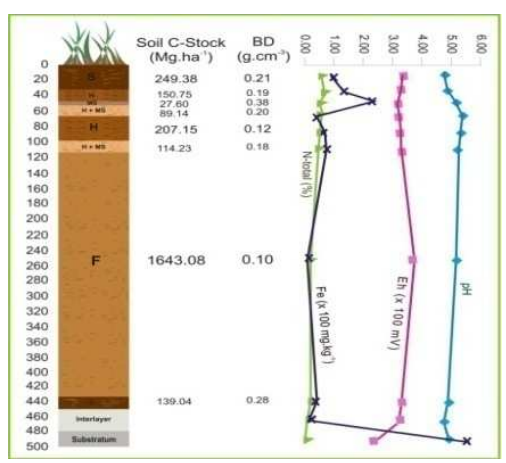

(8)

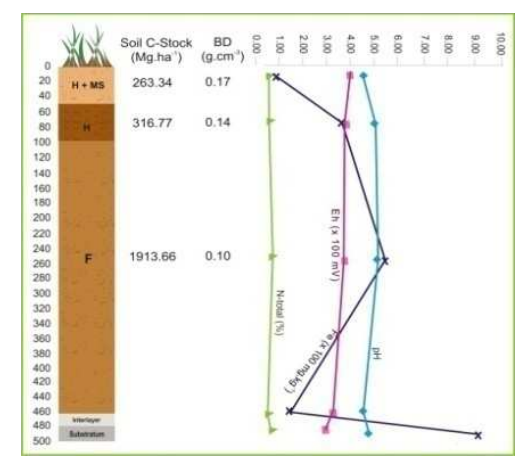

(9)

Note $: \mathrm{S}=$ Sapric $; \mathrm{H}=$ Hemic $; \mathrm{F}=$ Fibric $; \mathrm{MS}=$ Mineral Substance

Figure 1. Soil profile (the nine points of observation) at experiment sites.

Stratification of soil carbon stock and its relation to soil physic (BD) and chemical properties (soil $\mathrm{pH}$, Eh, Fe and N-total) can be seen in Figure 1. The figure shows a large 
difference of carbon stocks between each layers. Difference is due to mainly by differences the maturity degree of peat where sapric peat has higher carbon stock than hemic and fibric peat with successive ratio $2.0: 1.5: 1.0$. Soil at $>60 \mathrm{~cm}$ depth contained prevalent part of plant (roots and stems) which were still identifiable (plant residues) with $\geq 2 \mathrm{~mm}$ size and remnant (plant debris). Carbon stock calculations involving data BD and C-organic. Bulk density value increased with the increasing maturity of peat. However, increasing the value of $\mathrm{BD}$ is not only due to the maturation process of peat, but can also be caused by soil compaction process and the presence of mineral substance in peat layer. At this study, the high value of BD because of the presence of mineral substance in peat layer. There is no correlation between carbon stock with bulk density $\left(\mathrm{R}^{2}: 0.161\right)$.

Soil $\mathrm{pH}$ ranged between 4.48 to 5.19 , this value is higher than usual peat soil $\mathrm{pH}$ which is less than 4 . It can be caused by the influence of nutrient enrichment from river sediments. At some point observations the $\mathrm{pH}$ value increases with depth probably caused by a decrease in the production of organic acids, pore water mixing and changes in the composition of the peat matrix in greater depth (Shotyk, 1988). Indonesian peat dominated by lignin-rich woody plants. Biodegradation of lignin produces organic acids. Dissociation of organic acids will release ions $\mathrm{H}^{+}$in the soil solution. The concentration of ions $\mathrm{H}^{+}$determine soil acidification process, depend on the amount of ions $\mathrm{H}^{+}$produced and the amount of ions $\mathrm{H}^{+}$used or consumed. Carboxylate groups by lignin biodegradation play an important role in the process of acidification on peat soil.

Redox potential (Eh) tended to decrease with increasing soil depth. In this study, Eh values ranged between $+398 \mathrm{mV}$ to $+280 \mathrm{mV}$. According to Reddy and Delaune (2008) the values are considered as conditions of oxidative and slightly reductive. Ion $\mathrm{O}_{2}$ in the molecular $\mathrm{H}_{2} \mathrm{O}$ play a role as an electron acceptor reserve that causes slow changes in soil redox conditions. Soil redox conditions affecting the stability of iron compounds.
The complex humus material between $\mathrm{Fe}^{3+}$ can be very stable or otherwise depend on the molar ratio between the metal ions of organic acids, type of organic acids and environmental conditions such as ionic streght, redox potential and $\mathrm{pH}$. $\mathrm{Yu}$ et al. (2007) reported that soil $\mathrm{pH}$ variation negatively correlated with changes in the redox potential $(\mathrm{P}<0,01)$.

$\mathrm{N}$-total contents of peat soil varied according to degree of maturity and ranged from 1.05 to $0.22 \%$ and tended to decrease with increasing soil depth. Degree maturity of sapric has a higher $\mathrm{N}$ content than hemik and fibric. Soil Fe content at upper layer was high $\left(117.45-375.18 \mathrm{mg} \cdot \mathrm{kg}^{-1}\right)$ due to the presence of the mineral substance insertions. Results of data analysis showed that there was no significant relationship between carbon stock with some soil properties, such as BD $\left(R^{2}: 0.276\right), \mathrm{pH}\left(\mathrm{R}^{2}: 0.148\right)$, Eh $\left(\mathrm{R}^{2}: 0.044\right)$, Fe $\left(R^{2}: 0.113\right)$ dan N-total $\left(R^{2}: 0.083\right)$.

\section{CONCLUSION}

Variation in soil carbon stock at each layer of peat soil was due to difference in maturity degree of peat. Peat soil with sapric maturity degree has higher carbon stock than hemic and fibric with ratio of 2.0: 1.5: 1.0 respectively. The relationship between soil carbon stock with soil physic (BD) and chemical properties (soil $\mathrm{pH}, \mathrm{Eh}, \mathrm{Fe}$, and total-N) were not significant.

\section{REFERENCES}

Agus, F. 2009. Panduan Metode Pengukuran Karbon Tersimpan Di Lahan Gambut. Balai Besar Penelitian dan Pengembangan Sumberdaya Lahan Pertanian. Bogor and World Agroforestry Centre, SEA, Bogor, Indonesia

Borch, T., R. Kretzschmar, A. Kappler, P. Van-Cappalen, M. Ginder-Vogel, A. Voegelin and A. Campbell. 2010. Biogeochemical redox processes and their impact on contaminant dynamics. Environ. Sci. Technol. 44; 15-23. 
Hooijer A, M. Silvius, H. Wösten and S. Page. 2006. PEAT $\mathrm{CO}_{2}$, Assessment of $\mathrm{CO}_{2}$ Emission from drained peatlands in SE Asia. Wetland International and Delft Hydraulics report Q3943.

Joosten H. 2009. The Global Peatland CO2 Picture. Peatland status and drainage related emissions in all countries of the world. Wetlands International. www.wetlands.org. 35 p. Accesed on 20 March 2012.

Kiely G, NM McGoff, JM Eaton, X Xu, P Leahy and O Carton. 2009. Soil C Measuring and Modelling of Soil Carbon Stocks and Stock Changes in Irish Soils. EPA STRIVE PROGRAMME 2007-2013 Report. Environmental Protection Agency. Ireland. $37 \mathrm{p}$.

Morison J, E Vanguelova, S Broadmeadow, M Perks, S Yamulki and T Randle. 2010. Understanding the GHG implications of forestry on peat soils in Scotland. The Research Agency of the Forestry Commission. Scotland. $55 \mathrm{p}$.

Nurzakiah S, F Agus and H Syahbuddin. 2013. Ameliorant application on variation of carbon stock and ash content on peatland South Kalimantan. Trop Soils 18: 11-16.
Pagiola S. 2000. Land Use Change in Indonesia. In. World Bank. 2001. Background Paper for Indonesia: Environment and Natural Management in a Time of Transition. http://econwpa.wustl. edu:80/eps/othr/papers/

0405/0405007.pdf.

Reddy. K.R. and R.D. DeLaune. 2008. The Biogeochemisty of Wetlands; Science and Applications. CRC Press. New York, USA. $779 \mathrm{p}$.

Shotyk W. 1988. Review of the inorganic geochemistry of peats and peatland waters. Earth Science Reviews. 25: 95-176

Wardah, B Toknok and Zolkhaidah. 2011. Carbon stock of agroforestry systems at adjacent buffer zone of Lore Lindu National Park, Central Sulawesi. J Trop Soils 16: 123-128.

Wellock ML, B Reidy, CM Laperle, T Bolger and G Kiely. 2011. Soil organic carbon stocks of afforested peatlands in Ireland. Forestry 84: 441-451.

Yu K, F Böhme, J Rinklebe, HU Neue and R DeLaune. 2007. Major biogeochemical processes in soils-a microcosm incubation from reducing to oxidizing conditions. Soil. Sci. Soc. Am. J. 71 : 1406 - 1417. 